WSRC-MS-95-0151

CONF-9505238--3

SRS Vitrification Studies in Support of the U.S. Program for Dispositiion of Excess Plutonium (U)

by

G. G. Wicks

Westinghouse Savannah River Company

Savannah River Site

Aiken, South Carolina 29808

J. M. McKibben

M. J. Plodinec

W. G. Ramsey

A document prepared for NATO ADVANCED WORKSHOP ON "DISPOSITION OF WEAPONS PU-APPROACHES AND PROSPECTS"

TO BE PUBLISHED IN NATO TRANSACTIONS OF THE WORKSHOP, NATO ASI SERIES at St. Petersburg from 05/13/95 - 05/17/95.

DOE Contract No. DE-AC09-89SR18035

This paper was prepared in connection with work done under the above contract number with the U.S.

Department of Energy. By acceptance of this paper, the publisher and/or recipient acknowledges the U.S. Government's right to retain a nonexclusive, royalty-free license in and to any copyright covering this paper, along with the right to reproduce and to authorize others to reproduce all or part of the copyrighted paper.

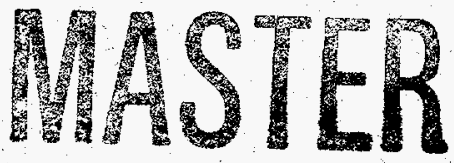




\section{DISCLAIMER}

This report was prepared as an account of work sponsored by an agency of the United States Government. Neither the United States Government nor any agency thereof, nor any of their employees, makes any warranty, express or implied, or assumes any legal liability or responsibility for the accuracy, completeness, or usefulness of any information, apparatus, product, or process disclosed, or represents that its use would not infringe privately owned rights: Reference herein to any specific commercial product, process, or service by trade name, trademark, manufacturer, or otherwise does not necessarily constitute or imply its endorsement, recommendation, or favoring by the United States Government or any agency thereof. The views and opinions of authors expressed herein do not necessarily state or reflect those of the United States Govemment or any agency thereof.

This report has been reproduced directly from the best available copy.

Available to DOE and DOE contractors from the Office of Scientific and Technical Information, P.O. Box 62, Oak Ridge, TN 37831; prices available from (615) 576-8401.

Available to the public from the National Technical Information Service, U.S. Department of Commerce, 5285 Port Royal Road, Springfield, VA 22161. 


\section{DISCLAIMER}

Portions of this document may be illegible in electronic image products. Images are produced from the best available original document. 
To be presented at the NATO Advanced Workshop on "Disposition of Weapons PuApproaches and Prospects", St. Petersburg, Russia, May 13-17, 1995

\title{
SRS VITRIFICATION STUDIES IN SUPPORT OF THE U.S. PROGRAM FOR DISPOSITION OF EXCESS PLUTONIUM [U]
}

\author{
George G. Wicks*, J. Mal McKibben, M. John Plodinec and William G. Ramsey, \\ Westinghouse Savannah River Company \\ P.O. Box 616, Aiken, South Carolina 29802 USA
}

\begin{abstract}
Many thousands of nuclear weapons are being retired in the U.S. and Russia as a result of nuclear disarmament activities. These efforts are expected to produce a surplus of about $50 \mathrm{MT}$ of weapons grade plutonium (Pu) in each country. In addition to this inventory, the U.S. Department of Energy (DOE) has more than 20 MT of Pu scrap, residue, etc., and Russia is also believed to have at least as much of this type of material. The entire surplus Pu inventories in the U.S. and Russia present a clear and immediate danger to national and international security. It is important that a solution be found to secure and manage this material effectively and that such an effort be implemented as quickly as possible.
\end{abstract}

One option under consideration is vitrification of $\mathrm{Pu}$ into a safe, durable, accountable, and proliferation-resistant form. As a result of decades of experience within the DOE community involving vitrification of a variety of hazardous and radioactive wastes, this existing technology can now be expanded to include immobilization of large amounts of $\mathrm{Pu}$. This technology can then be implemented rapidly using the many existing resources currently available. An overall strategy to vitrify many different types of Pu will be discussed. In this strategy, the arsenal of vitrification tools, procedures and techniques already developed throughout the waste management community can be used in a staged Pu vitrification effort. This approach uses the flexible vitrification technology already available and can even be made portable so that it may be brought to the source and ultimately, used to produce a consistent and common borosilicate glass composition for the vitrified $\mathrm{Pu}$. The final composition of this product can be made similar to nationally and internationally accepted HLW glasses.

\section{BACKGROUND}

In January of 1994, the Committee on International Security and Arms Control (CISAC) of the National Academy of Sciences (NAS) issued a report entitled "Management and Disposition of Excess Pu" [1]. The purpose of this study was to evaluate disposition alternatives for management of excess plutonium resulting from disarmament activities. The treatise covered many important aspects of the Pu disposition question and with respect to long-term management of the excess Pu stated the following:

"The two most promising alternatives for achieving these aims (long-term $\mathrm{Pu}$ disposition) are:

- fabrication and use as fuel, without reprocessing, in existing or modified nuclear reactors; or

- vitrification in combination with high-level radioactive waste." 
A third option involving burial of Pu in deep boreholes was also mentioned for possible future consideration.

As a result of the NAS study, the vitrification option was elevated to the same level of importance as a reactor option and listed as one of two leading preferences for ultimate disposition of weapons grade $\mathrm{Pu}$.

The Savannah River Site (SRS) has been involved in vitrification of high level waste for several decades and also associated with vitrification of a variety of other types of radioactive and non-radioactive materials $[2,3]$. As a result of over 20 years of vitrification experience and about 40 years of $\mathrm{Pu}$ handing and processing experience, the site has been requested to provide input into this subject by several agencies, including the U.S. Department of Energy. These efforts are directed at addressing a variety of Pu disposition alternatives [4-7], including management of weapons grade $\mathrm{Pu}$ and also Pu scrap, residues, etc. that currently exist throughout the DOE complex. An early summary of vitrification options as well as a recent update of the advantages of this technology are presented elsewhere $[8,9]$.

\section{POTENTIAL ADVANTAGES OF VITRIFICATION}

There are many potential advantages associated with the vitrification option for longterm management of plutonium. These include the following:

Immediacy of Implementation:

Many experts in the field believe it is important to act quickly to immobilize Pu for security, safeguards, safety and environmental reasons. Because of the advanced state of the art of vitrification and as a result of the existing capabilities and experience in this area, there is no other Pu option that can be implemented as rapidly.

\section{Flexibility:}

The vitrification option provides a common technology for treatment of almost all forms of $\mathrm{Pu}$. This includes not only weapons grade $\mathrm{Pu}$, but also significant quantities of more complex Pu scrap and residue compositions, currently existing within the DOE community and posing additional problems.

\section{Technology Availability:}

As a result of the High Level Waste program and associated waste management efforts, the techniques and procedures for vitrifying radioactive and hazardous components are mature, the equipment and facilities for immobilizing actinides are available, and waste form specifications to assure product quality are well understood. These efforts are directly applicable to Pu vitrification and could be "piggy-backed" upon. A very extensive and capable vitrification infrastructure exists containing experienced and dedicated experts throughout federal and national laboratories, academia, and industry throughout the United States as well as in other countries.

\section{Waste Glass Performance:}

HLW glasses have been demonstrated to have excellent chemical durability, mechanical integrity, radiation and thermal stability. Chemical durability is considered to be the 
most important technical performance property of a waste glass form. It is important to note that actinide bearing glasses exhibit excellent chemical durability. The leaching of actinides is generally $10-100 x$ better (lower leach rates) than modifiers or alkali cations contained in HLW waste glass systems.

\section{Processing Considerations:}

The ability to vitrify radioactive materials is not only well developed, but also well demonstrated. In the case of HLW, actual production facilities are in operation worldwide. These include the French process in Marcoule and also La Hague, the German vitrification operation in Mol Belgium, the Sellafield facility in England and others. Construction of the first HLW vitrification facility in the United States, the Defense Waste Processing Facility (DWPF) at SRS, has recently been completed and is scheduled to be in production in about one year. Vitrification of Pu represents an extension of this already available vitrification technology and its many components.

\section{Waste Minimization:}

Due to the type of equipment and buildings needed to process radioactive materials, and as a result of the vitrification facilities and equipment used to treat other types of radioactive wastes, existing contaminated and non-contaminated facilities could be modified to perform Pu vitrification. These facilities include buildings and equipment designed to receive $\mathrm{Pu}$, store the material, process the $\mathrm{Pu}$, and vitrify it into acceptable products. These facilities currently exist within the DOE complex and although they would require various degrees of modification, their existence would eliminate the need to build and later D\&D additional buildings.

\section{Ability to Immobilize Pu in Glass:}

Immobilization of Pu into borosilicate glass has already been demonstrated in HLW programs. This early work involved immobilization of $7 \mathrm{wt}$. \% of plutonium oxide into a glass matrix [10]. Higher Pu loading is probable. Hence, there is no question whether Pu can be vitrified- the maximum amount immobilized remains to be defined and will most likely not be determined by solubility limits but by criticality considerations.

\section{Inherent Criticality Control:}

Due to the composition of borosilicate glasses, boron as well as lithium, which are normally present in HLW forms, can act as poisons to assist in criticality control. This is especially important during handling and processing operations. Other poisons such as gadolinium or erbium could be added to further this effect, which would be especially relevant for long-term repository storage scenarios due to their insolubility. Additional work would be necessary to better assess the effects of potential poisons for criticality control in some of the final disposal options under consideration and for increasing the difficulty in reclaiming $\mathrm{Pu}$ from the glass matrix. Criticality control represents the most important consideration in all stages of any disposal option.

\section{Acceptability/ Waste Form Qualifications:}

The only waste form which has achieved a degree of national and international acceptance for immobilizing HLW is borosilicate glass. HLW glasses already contain Pu, although in small amounts. It took approximately ten years and thirty million dollars to qualify the 
SRS HLW waste glass composition. This important and necessary effort could be piggybacked upon for the Pu vitrification option.

\section{Proliferation Resistance:}

There are many ways in which $\mathrm{Pu}$ can be immobilized into glass to produce durable, safe, proliferation-resistant forms. These options depend on the degree of proliferation resistance required and are directly proportional to the cost and complexity of the operation. For example, simply immobilizing $\mathrm{Pu}$ into glass can be achieved rapidly and most easily and provides the highest degree of flexibility. The Pu-glass product produced would be more proliferation resistant that $\mathrm{Pu}$ in its weapons form, but could be reclaimed fairly easily by those reasonably familiar with this field. The degree of proliferation resistance could be increased significantly, however, by either initially mixing the Pu directly or by re-melting Pu-only glass, with fission products or existing HLW. The radiation field associated with the radioactive additives would considerably increase the difficulty in obtaining or handling this material and in subsequent transportation and reprocessing operations to reclaim $\mathrm{Pu}$. Proliferation resistance can be further enhanced by the potential size and weight of the product, chemistry of the form, and most important, by the safeguards that would be necessary for any undertaking of this type.

\section{OVERVIEW OF A POTENTIAL PU VITRIFICATION STRATEGY}

Vitrification provides an important option to immobilize and dispose of not only weapons grade $\mathrm{Pu}$, but also many other forms of $\mathrm{Pu}$ as well as other radionuclides of concern currently existing in weapons producing nations. Major steps involved in a $\mathrm{Pu}$ vitrification strategy include Pu handling and glass preparation, conversion to melter feed, vitrification into intermediate or final Pu-glass products, interim storage of $\mathrm{Pu}$ glass forms and final product dispositon.

A simplified flowsheet summarizing this overall vitrification strategy is shown in Figure 1 following is a brief description of each of the important phases.

\section{Preparation:}

The vitrification strategy applies to $\mathrm{Pu}$ in metal form currently contained in weapons as well as $\mathrm{Pu}$ in other forms such as oxides, buttons, scrap, solutions, ash, salts, residues, etc. The other forms of Pu are contained at DOE sites including Rocky Flats, Los Alamos National Laboratory, Hanford, Argonne National Laboratory, Idaho National Engineering Laboratory, and the Savannah River Site. Preparation of these materials will involve receipt, disassembly/ separations in some cases, assaying, interim storage and pretreatment prior to immobilization.

\section{Conversion:}

There are two major options that can be used for conversion of Pu from a metallic form to a suitable melter feed. These include (a) oxidation-burning it to produce plutonium oxide powder and (b) dissolution- dissolving it to yield a plutonium acid solution. Additional preparation involving Pu scrap and residues could be performed, depending on composition and subsequent melting characteristics. Vitrification can handle either liquid or oxide feeds. 


\section{Vitrification:}

A vast array of electric melting techniques have been developed for vitrification of radioactive wastes over the years and include indirect heating, joule heating, plasma and microwave vitrification. Many of these technologies and could be utilized for vitrification of $\mathrm{Pu}$. The proposed strategy considers two main options for vitrification:

- Direct Vitrification; A direct means of vitrifying Pu into glass is shown as Option A in Figure 1. In this case, the treated $\mathrm{Pu}$ is melted directly with fission products such as $\mathrm{Cs}-137$ or HLW to produce a highly radioactive Pu glass product. This could be accomplished in several ways and provides the most immediate highest degree of proliferation resistance. Because of the highly radioactive wastes to be mixed with the $\mathrm{Pu}$, specially contained and heavily shielded facilities would be necessary.

- Staged Vitrification Approach; A two-staged vitrification option is given as Option B in Figure 1. First, a Pu-only glass is produced as an interim product. This step has the advantage of being able to be implemented very rapidly and most easily due to the relatively low amounts of radioactivity present, resulting from the initial absence of fission products or HLW that would be added later. The production of this interim product increases the flexibility of the process in that it can be performed by the use of relatively simple equipment in gloveboxes, and the process can even be made portable, if desired. It also allows use of a wide range of different site-specific vitrification technologies that exist and are already located at sites containing some of the waste. While the resulting Pu-only glass does not produce the most proliferation resistant glass product initially, it does provide the most flexibility. This flexibility allows interim products to be transported to other locations that have more highly radioactive wastes, such as HLW or selected fission products, and later be re-melted or recombined with this waste to produce more proliferation resistant forms. Specially contained facilities and equipment similar to the Direct Vitrification option would also be necessary for this final part of the operation. However, by using the staged approach, this mission involving Pu immobilization could be most easily and efficiently meshed into other existing facilities, programs and subsequent schedules to produce an optimum use of existing resources.

An important part of the Pu vitrification strategy discussed above is that for either option, Direct or Staged Vitrification, a common final waste glass form can be produced with a composition similar to HLW glass [11]. The HLW glass composition has already undergone a very time consuming and expensive process to be certified and made acceptable. A resulting Pu bearing glass can "piggy-back" on this work. The Pu glass compositions would be expected to be as good, if not better, than the already acceptable HLW glass compositions. In general, the observed "leachability" of actinides in glass matrices is significantly lower (better) than most other components found in waste glass systems.

\section{Interim Product Storage:}

A need to store Pu bearing glasses temporarily is important to the vitrification option. The design of the interim storage facility would depend on factors such as the composition and radioactive content of the products and the intended duration of storage before ultimate disposal. Among the most important considerations for this facility are worker radiation exposure, public and environmental protection from radiologic hazards, and material safeguards and accountability. 


\section{Final Product Disposition:}

The reference concept for ultimate disposition of HLW glass and spent fuel is to dispose of this material by deep burial in carefully selected geologic repositories. This is also being considered for Pu bearing glasses. A very significant challenge for any repository scenario is to demonstrate safe and effective performance of products out to very long time periods ( 1000 to 10,000 years, and longer). This challenge would be expected to be even more formidable for any immobilization alternative containing large amounts of $\mathrm{Pu}$, due to criticality considerations. The waste form and waste package will be designed to prevent criticality from occurring but this must be demonstrated to a very. high degree in a very complex environment. While this would not be expected to be as significant an undertaking for a "Retrievable Surface Storage Facility or RSSF", it would be expected to take much more effort to demonstrate in a geologic repository.

The final form and composition of Pu glass would be tailored for technical and political considerations, involving possible reuse or non-reuse by the weapons producer and for optimizing proliferation resistance, especially towards potential non-friendly nations.

\section{VITRIFICATION FACILITIES \& CAPABILITIES}

\section{Vitrification of Pu Using New Facilities:}

One of the options being considered for immobilization of $\mathrm{Pu}$ is to design new plants, buildings and equipment tailored for Pu processing. This is referred to as the "Greenfield Option". A potential main advantage of this alternative is that facilities can be designed for optimum performance to accomplish the mission. Main disadvantages include possible increased costs, time for implementation and the dispositon of facilities which must ultimately be decontaminated and decommissioned after completion of the campaign. A variety of immobilization options involving not only glass but other alternatives, as well as various immobilization techniques and technologies using new as well as existing facilities, are now being evaulated for disposition of surplus fissile materials in the United Statess [12]. A Programmatic Environmental Impact Statement or PEIS is in draft on these options.

\section{Vitrification of Pu Using Existing Facilities:}

As discussed earlier, there exists an infrastructure knowledgeable on vitrification of radioactive and hazardous wastes that could be applied to vitrification of $\mathrm{Pu}$. For example, there have already been several technology exchanges between U.S. and Russian scientists on possible joint efforts involving vitrification of a variety of radioactive wastes, including actinide-bearing materials. Further exchanges and interactions are also planned. Immobilization of Pu scrap and residues are of immediate interest within the U.S. DOE complex and these efforts could also be extended to include immobilization of $\mathrm{Pu}$ derived from weapons dismantlement activities.

Along with developed and demonstrated vitrification technology, experience and expertise, there also exists buildings, equipment and supporting hardware as well as software for immobilization efforts. In support of the NAS study, the Savannah River Site was asked in 1993 to perform a study examining vitrification options for Pu using facilities and capabilities that already existed. While capabilities exist throughout the DOE complex for this task, those at the Savannah River Site (SRS) were emphasized. Following are some of the results of this study including examples of types of facilities needed [8]. 
Five major Pu vitrification options, along with variations of most of these options, were identified using SRS facilities for this study [8]. The processing options involved three potential $\mathrm{Pu}$-bearing products that could be made; Pu-only glass (interim product), $\mathrm{Pu} / \mathrm{Cs}-137$ glass (final product) or Pu/HLW glass (final product). Examples of types of relevant existing facilities which could be modified and would be important to support vitrification of plutonium include the following:

- Plutonium Storage Facility (PSF); The PSF along with New Special Recovery are facilities that are part of the 221-F Canyon building located at SRS. This complex is shown in Figure 2. The mission of the PSF was to receive Pu materials from offsite that would later be processed. The building contains a fully safequarded vault for automated transport and stacking, gloveboxes for opening drums and removing and inspecting contents, and instruments for non-destructive assay and computer accountability. The facility also contains a delivery systems for later processing of materials in the adjacent facility, the New Special Recovery (NSR).

- New Special Recovery (NSR); The mission of the NSR was to process plutonium from throughout the DOE complex. This includes dissolving Pu scrap, oxide or metal from various sources to produce purified Pu metal buttons or oxide powder. The facility contains state of the art glovebox trains (Figure 3 ) for feed preparation, waste handling, dissolution processes, samples and analysis, along with a supporting remote control room. This facility also contains extra room which could be outfitted with glass melters to pursue one of the vitrification options under consideration.

- E Canyon (Including the Multi-Purpose Processing Facility or MPPF); The 221-F Canyon was the world's first PUREX production plant used to dissolve natural and depleted uranium targets and to recover the uranium and plutonium. It is a large, heavily shielded facility operated by remote means. The building has the potential of being refitted with a melter and used for vitrification in support of another vitrification option of immobilizing Pu directly with HLW or selected fission products. The MPPF is located within the facility and contains eight modules that are now being used for vitrification of $\mathrm{Cm}$ and $\mathrm{Am}$ using a bushing melter, and will also be used for vitrification and subsequent clean up of Pu scrap on site.

- Defense Waste Processing Facility (DWPF); The DWPF is the first major waste vitrification facility constructed in the United States for immobilization of high level radioactive waste (HLW). It is scheduled to be in production in about one year. The mission of the DWPF, shown in Figure 4, is to immobilize the $\mathbf{3 4}$ million gallons of HLW currently being stored at SRS into borosilicate glass. All of the operations necessary to process, vitrify, containerize, seal and decontaminate HLW glass units are present, including supporting capabilities to control the process and verify product quality. This facility and its equipment could be modified in support of various options to vitrify larger quantities of Pu than presently contained within HLW.

Important for DWPF options is not to adversely affect the current, important mission of the facility. There are two primary ways that $\mathrm{Pu}$ vitrification could be conducted using the DWPF. First, during the scheduled melter change out of the DWPF, the facility and equipment could be modified and Pu bearing feed introduced either directly as a Pu feed or as a Pu bearing glass frit, to produce Pu-HLW glass forms in $304 \mathrm{~L}$ stainless steel containers. These units would be similar to HLW glasses in canisters, $2-\mathrm{ft}$. in diameter and almost 10-ft. high. An important potential advantage of this option is that waste loading to the glass could be increased by $1-2 \%$, which would still result in a highly 
durable form which could immobilize $50 \mathrm{MT}$ of Pu as part of the HLW program, and without increasing the number of waste canisters produced. Important disadvantages of this option are that the facility is not currently designed nor approved to handle large amounts of fissile material and to do so, additional criticality controls would be needed. This would be expected to be both expensive and very time consuming, and presents the potential of adversely affecting the existing HLW program.

An alternative or second main option is designed to minimize the potential disadvantages discussed above and allow immobilization of excess Pu to be started sooner. This option involves the staged approach discussed earlier, in which a Pu-only interim glass form is first made and later, mixed with fission products or HLW to produce a $\mathrm{Pu} / \mathrm{FP}$ or $\mathrm{Pu} /$ HLW final glass product. A means to accomplish this task using the DWPF facility and its extensive capabilties is by the "can-in-canister" method. This involves placing cans of interim Pu-only glass produced earlier in more convenient and available facilities into a rack in HLW canisters and then pouring HLW around them in the DWPF as part of the current HLW vitrification campaign. While this option may not produce as integral a product as the direct vitrification of Pu-HLW glass, it would be expected to produce a excellent form with a high radiation field, very heavy, cumbersome in size, and subsequently, high proliferation protection. This approach not only represents the easiest and most rapid to engineer, but could be the least expensive to implement. It also represents an option of maximum flexibility that can utilize existing facilities in an efficient manner by allowing Pu immobilization to fit into existing schedules, programs and buildings, without adversely effecting other efforts.

\section{Current Vitrification Studies on Actinides (Th, U, Am, Cm \& Pu):}

The Savannah River Technology Center is actively investigating actinide glass formulations as part of current waste management and environmental remediation efforts. Studies are in progress to (a) demonstrate the feasibility of immobilizing actinides into glass, (b) determine the maximum concentration of actinides that can be loaded into a glass and (c) evaluate both the processability and chemical durability of a variety of potential actinide glass formulations. Glass samples have been prepared with $\mathrm{Th}, \mathrm{U}, \mathrm{Am}, \mathrm{Cm}$ and $\mathrm{Pu}$ [13]. A commercial borosilicate glass composition was seen to accept up to 9 mole percent (approximately 20 weight percent) $\mathrm{ThO}_{2}$ or $\mathrm{UO}_{2}$, and $\mathrm{PuO}_{2}$ has been successfully added to a glass composition at a level of 6.6 mole percent (15 weight percent). Am and $\mathrm{Cm}$ glasses have also been fabricated. Characterization and optimization of these systems are in progress.

Löffler glass, the borosilicate composition discussed above, is one of the glass systems under study. This glass has been shown to exhibit very good chemical durability. This is exemplified in Figure 5 which shows a plot of the chemical durability of several Löffler glasses made with rare earth surrogates for the actinides compared to more common glasses of known excellent durability, i.e., fused silica and $v y c 0 r{ }^{\circledR}$. The addition of the various actinide surrogates appear to have little effect on the excellent chemical durability of the Löffler glass. The durability of glasses with increasing concentrations of actual $\mathrm{ThO}_{2}$ and $\mathrm{UO}_{2}$ is summarized in Figure 6. These data indicate that the Löfler glass is both highly compatible with actinides and extremely resistant to aqueous attack.

\section{SUMMARY}

Vitrification is a technically viable option to immobilize and manage Pu resulting from disarmament activities as well as a wide range of existing Pu scrap and residue 
compositions. A vitrification infrastructure exists from waste management programs. This includes expertise and experience, personnel, buildings, equipment and supporting capabilities, which could be used to implement vitrification of $\mathrm{Pu}$ in a time expedient and cost effective manner.

\section{REFERENCES}

1 COMMITTEE ON INTERNATIONAL SECURITY AND ARMS CONTROL, National Academy of Sciences, "Management and Disposition of Excess Weapons Plutonium", National Academy Press, Washington DC (1994).

2 M.J. PLODINEC, G.G. WICKS, and N.E. BIBLER, "An Assessment of Savannah River Borosilicate Glass in the Repository Environment", DP-1629, Savannah River Laboratory, Aiken SC (1982).

3 G.G. WICKS, "Nuclear Waste Glasses", in Ireatise on Materials Science and Technology. Glass IV, M. Tomozawa and R.H. Doremus, eds., Vol. 26, pp. 57-188, Academic Press, Inc. (1985).

4 G.G. WICKS, "Advantages and Limitations of Disposing of Pu in Glass", presented to the Committee on International Security and Arms Control, National Academy of Sciences, Washington DC (1993).

5 J.M. MCKIBBEN and G.G. WICKS, "Vitrification of Excess Plutonium", presented at the International Policy Forum: Management \& Disposition of Nuclear Weapons Materials, Leesburg, VA (1994).

6 G.G. WICKS, J.M. MCKIBBEN and M.J. PLODINEC, "Vitrification of Plutonium", presented to the Interagency Working Group on Plutonium Disposition, Aiken SC (1994).

7 G.G. WICKS, M.J. PLODINEC, and J.M. MCKIBBEN, "Leveraging of Resources for Vitrification of Plutonium", presented to the Immobilization Task Team on Plutonium Disposition, Aiken SC (1994).

8 J.M. MCKIBBEN, R.W. BENJAMIN, D.F. BICKFORD, L.P. FERNANDEZ, W.N. JACKSON, W.R. MCDONELL,E.N. MOORE, P.B. PARKS, M.J. PLODINEC, W.M. RAJCZAK, S.K. SKILES, and G.G. WICKS, "Vitrification of Excess Plutonium (U)", WSRC-RP-93-755, Predecisional Draft, Westinghouse Savannah River Company (1993).

9 G.G. WICKS, J.M. MCKIBBEN and M.J. PLODINEC, "Vitrification for Disposition of Excess Plutonium", presented at Waste Management '95, Tucson, AZ, Feb. 26- Mar. 2, 1995 and to be published in the proceedings (1995).

10 M.J. PLODINEC "Development of Glass Compositions for Immobilization of SRP Waste", DP-1517, Savannah River Site (1979).

11 W.G. RAMSEY and G.G. WICKS, "WIPP/SRL In-Situ Tests: Compositional Correlations of MIIT Waste Glasses", in Ceramic Transactions, Nuclear Waste Management III, G.B. Mellinger, ed., Vol. 9, pp. 257-270 (1990).

12 L.W. GRAY, "Pu Immobilization: Progress, Challenges, and Path Forward", presented at the 2 nd International Policy Forum: Management \& Disposition of Nuclear Weapons Materials", Lansdowne, VA, March 21-24 (1995).

13 W.G. RAMSEY, N.E. BIBLER and T.F. MEAKER, "Compositions and Durabilities of Glasses for Immobilization of Plutonium and Uranium", presented at Waste Management '95, Tucson, AZ, Feb. 26- Mar. 2, 1995 and to be published in the proceedings (1995). 


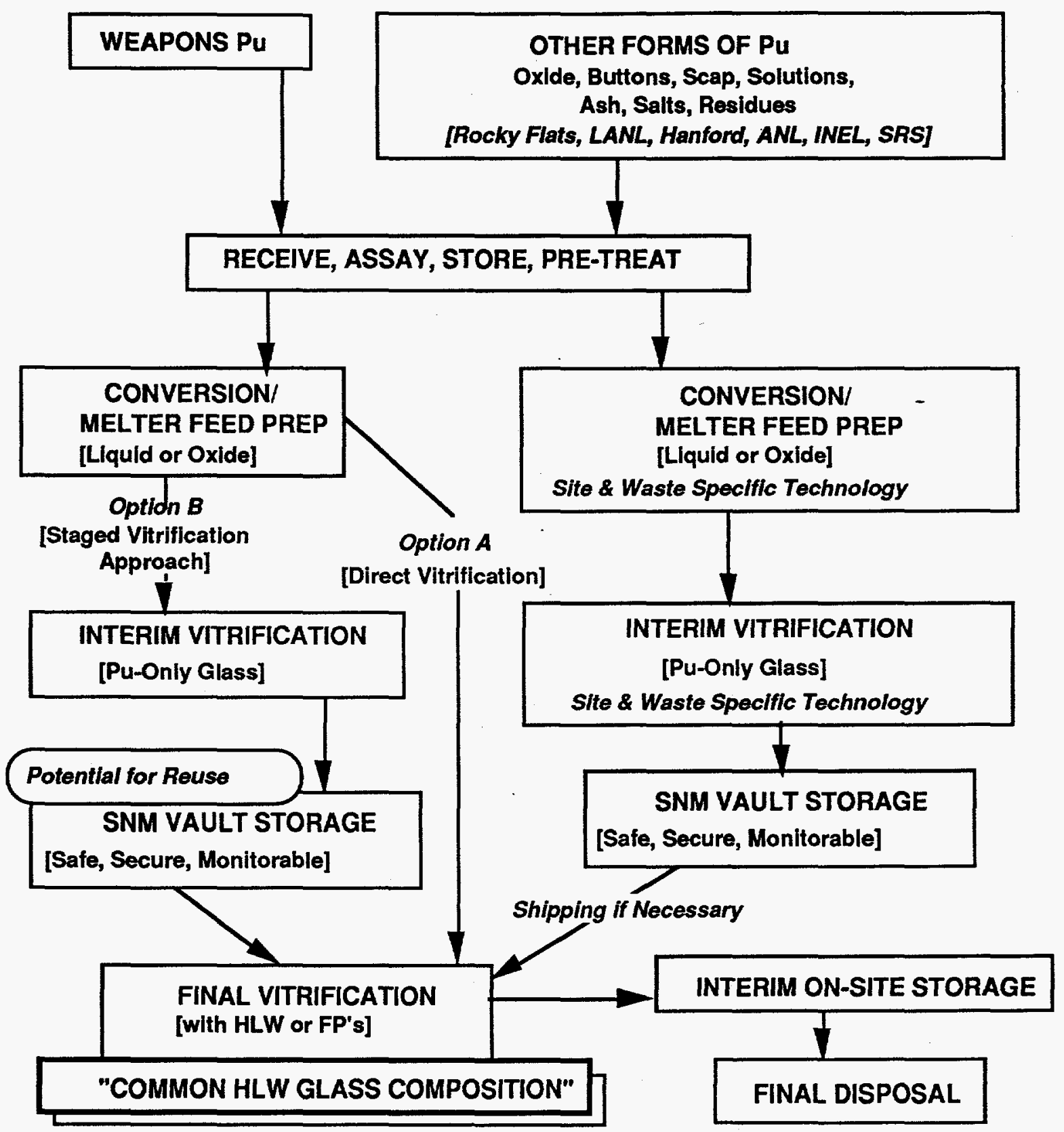

Figure 1. Overall Pu Vitrification Strategy 


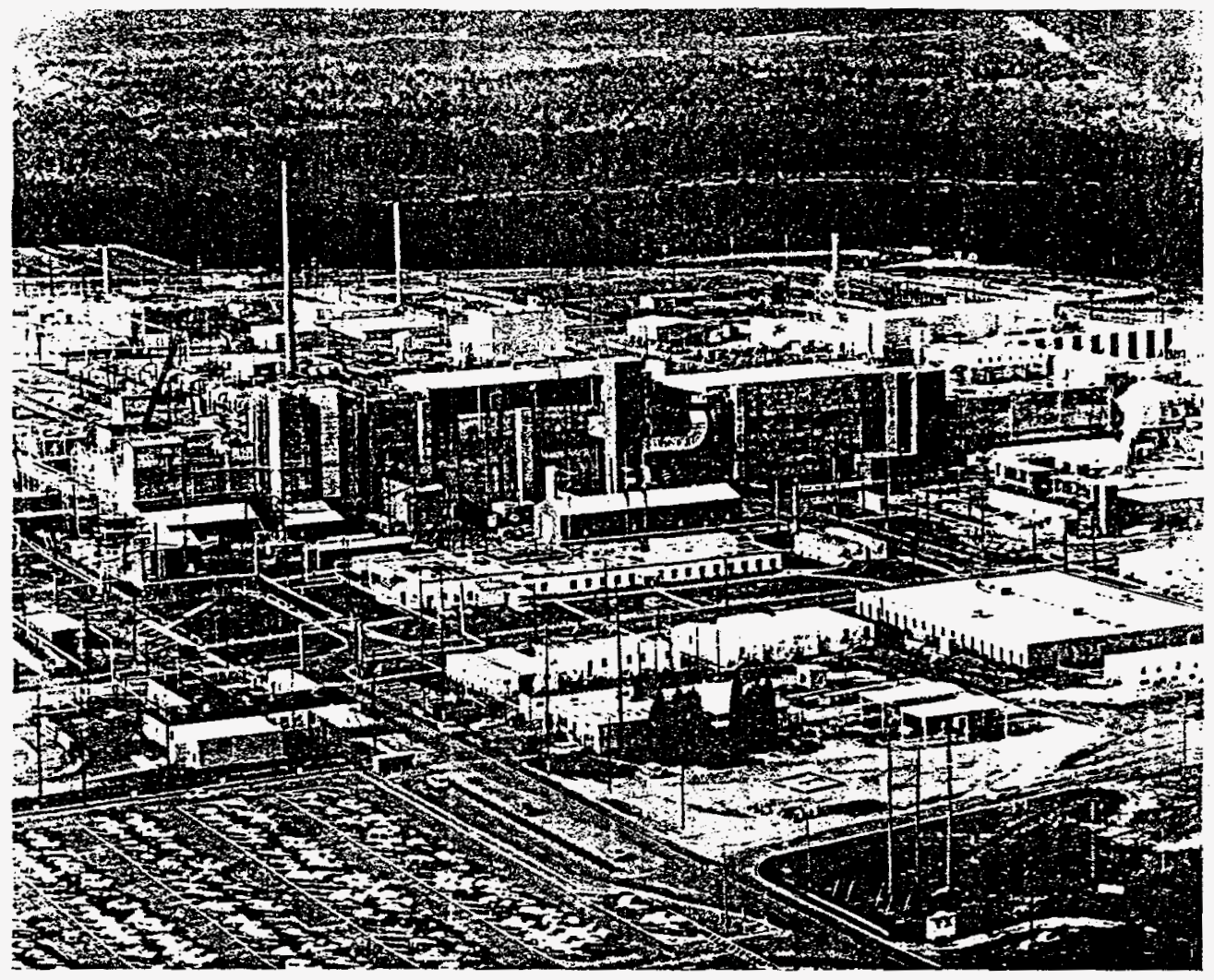

Figure 2. Building 221-F, NSR, and PSF Facilities (89-2076-18)

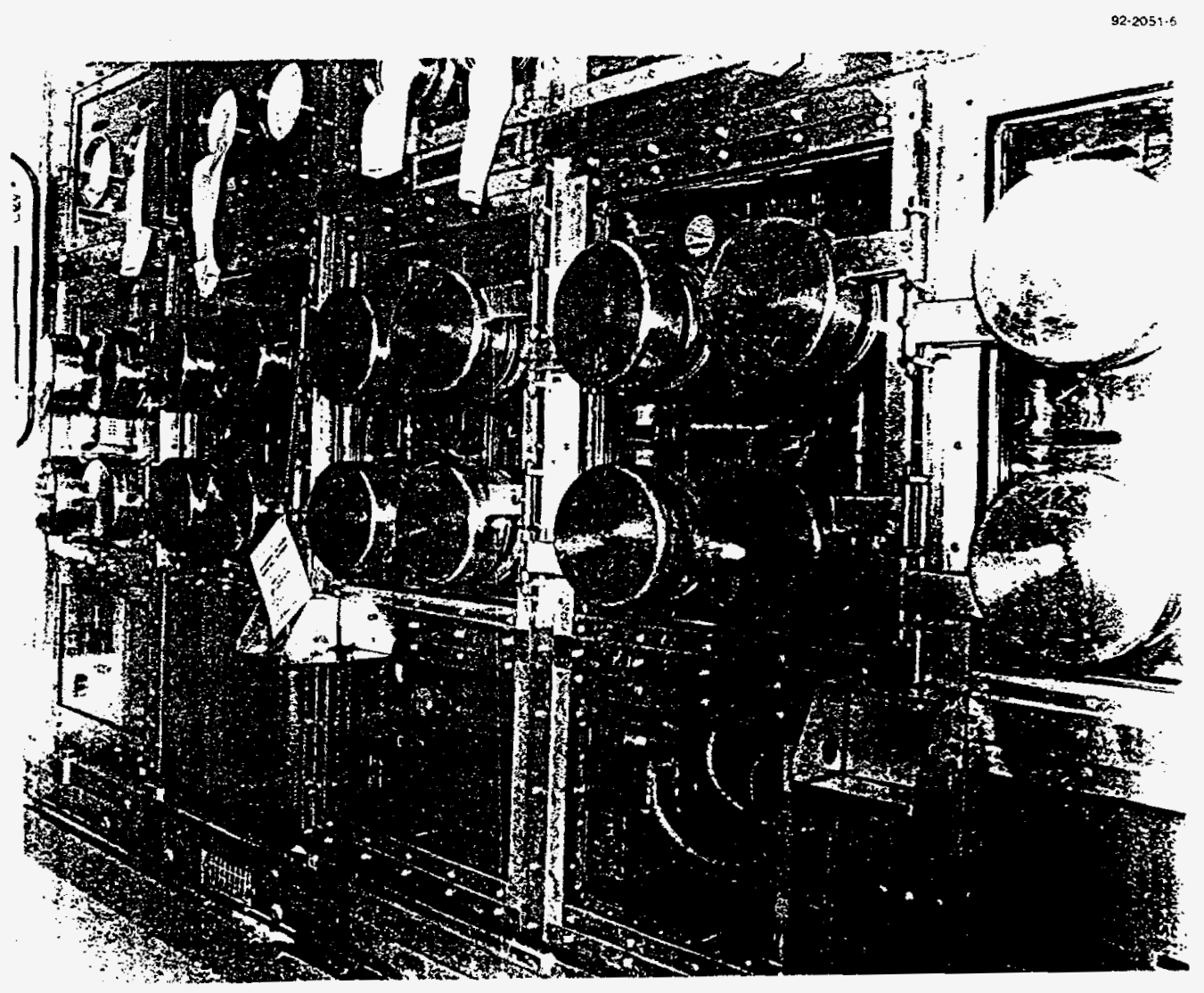

Figure 3, Gloveboxes in NSR (92-2051-6, altered) 


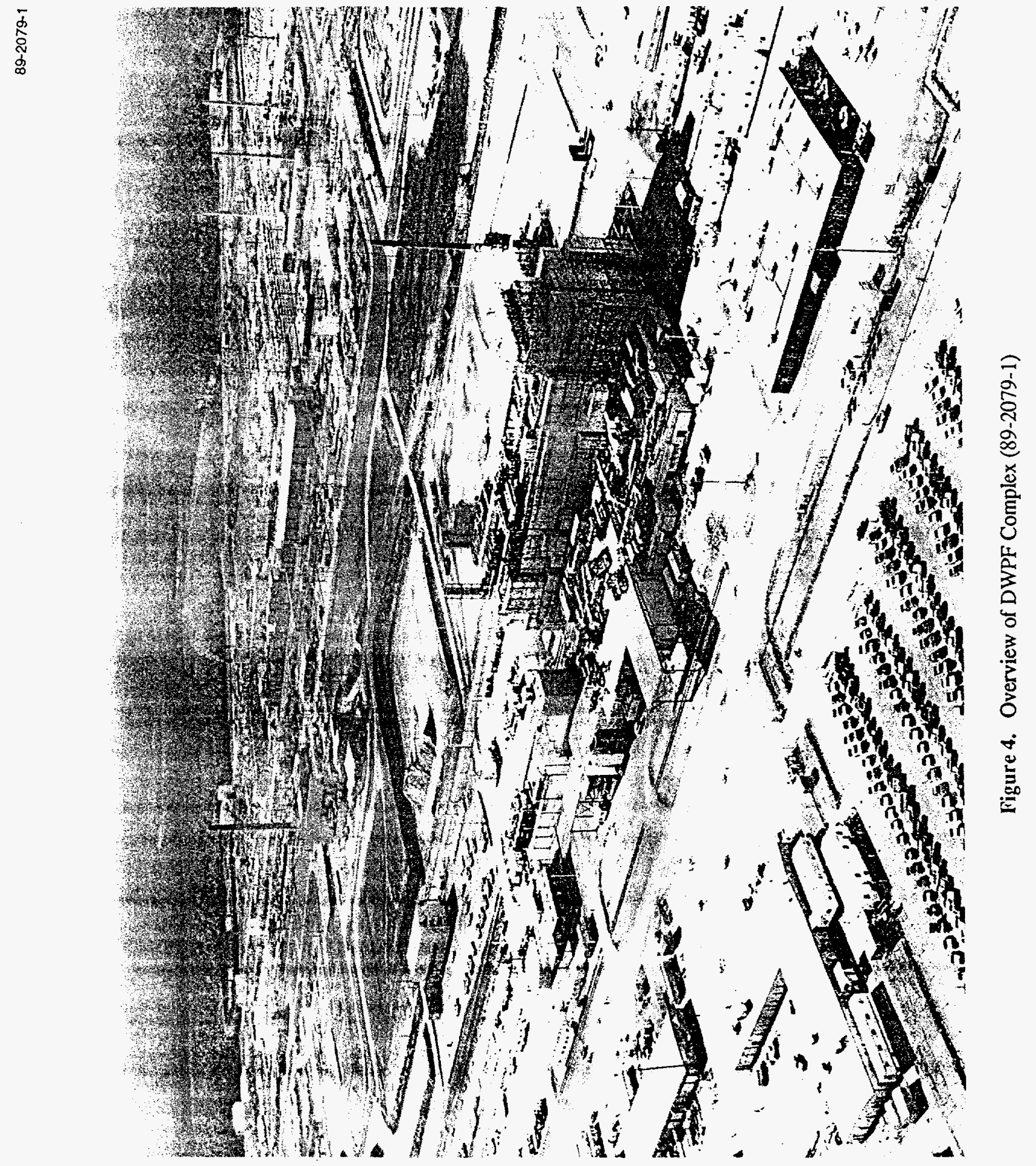




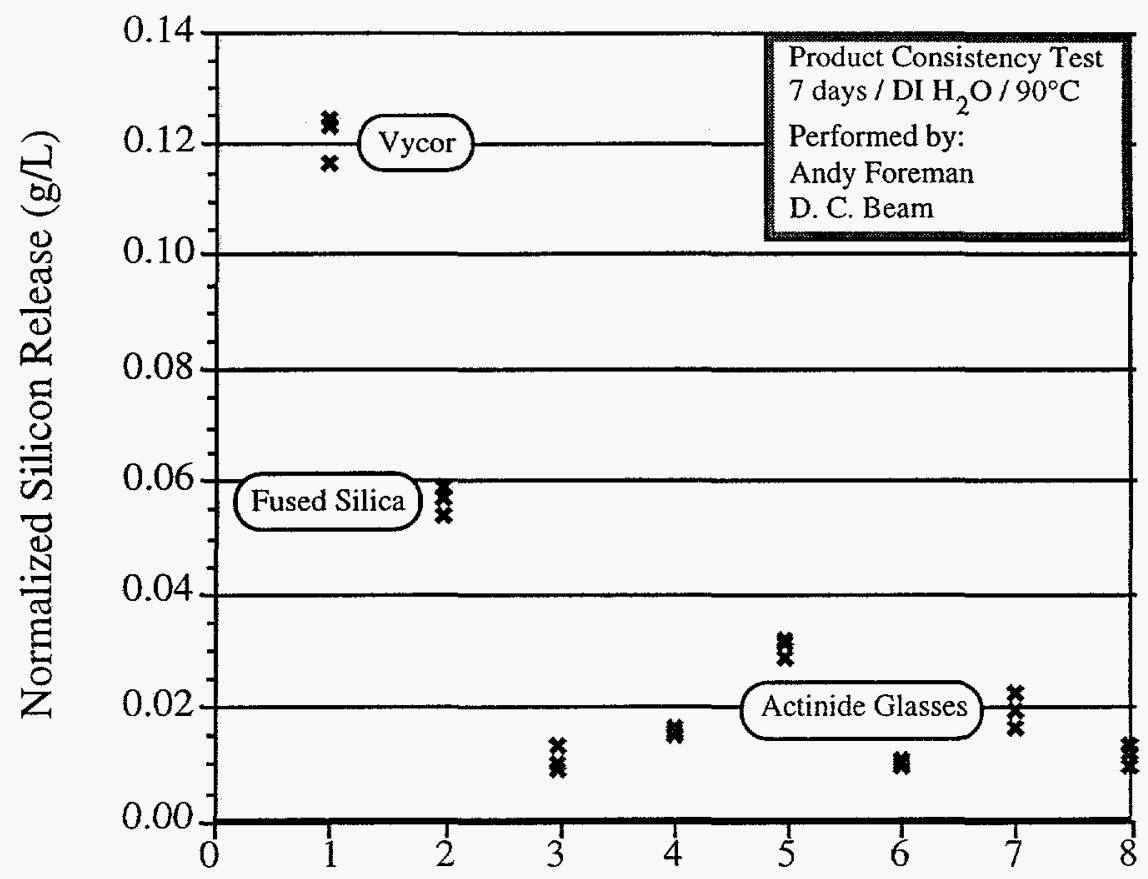

Glass Identification Number

Figure 5. Relative Durability of Löffler Glasses and Common Leach Resistant Glasses.

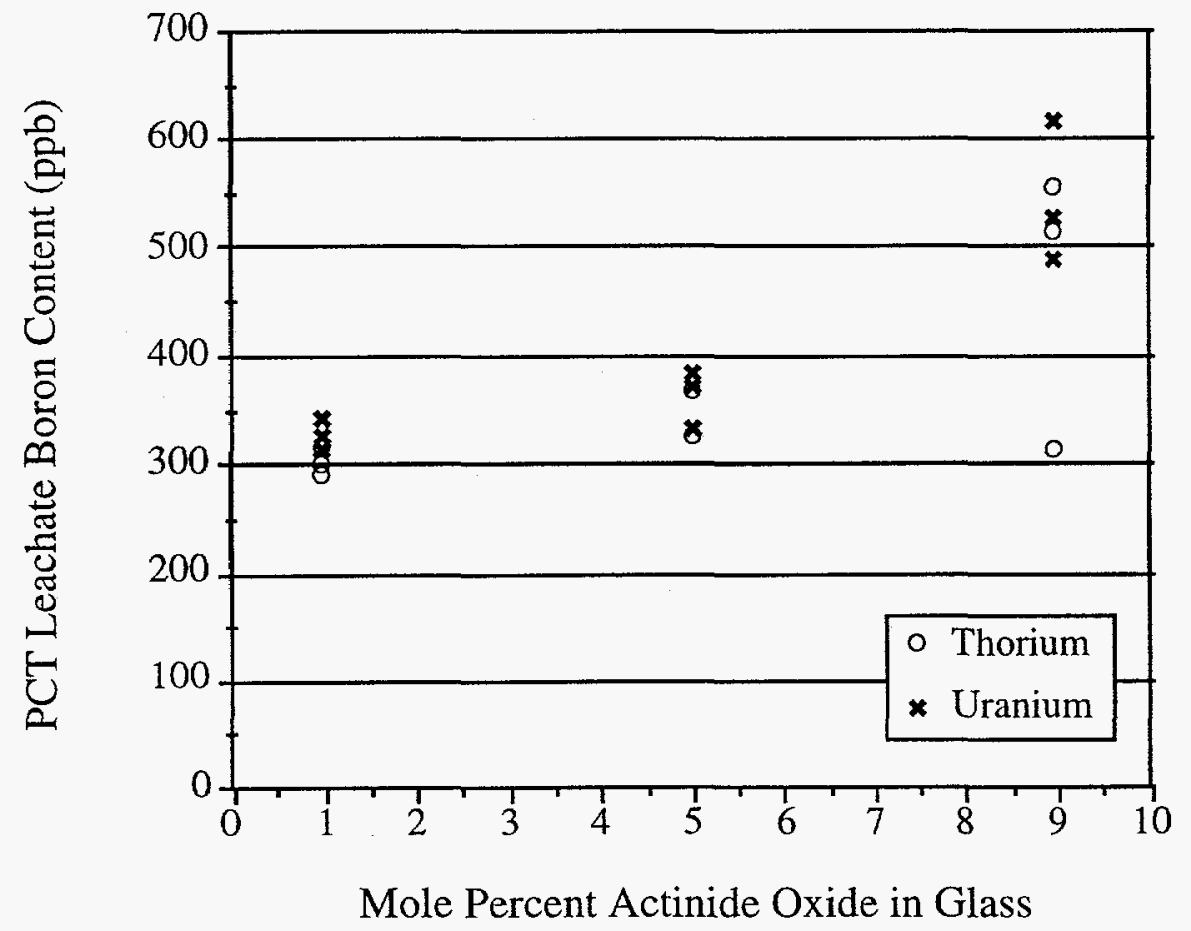

Figure 6. Effect of Actinide Oxide Concentration on Löffler Glass Durability. 